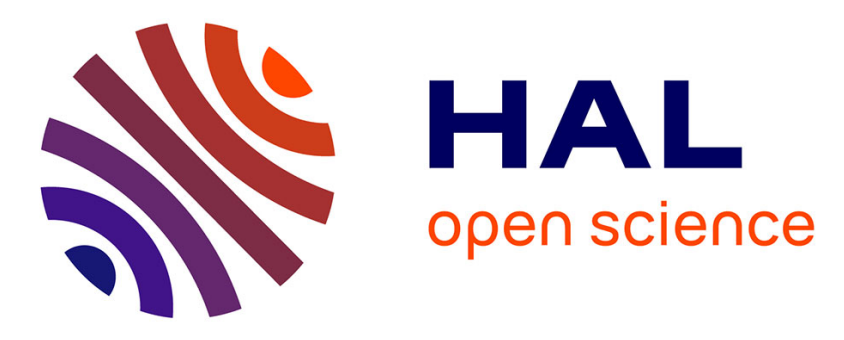

\title{
Endocrine disruption in wild populations of chub (Leuciscus cephalus) in contaminated French streams
}

Nathalie Hinfray, Olivier Palluel, Benjamin Piccini, Wilfried Sanchez, Selim Ait-Aissa, Patrice Noury, Elena Gomez, Perrine Geroudie, Christophe Minier, François Brion, et al.

\section{To cite this version:}

Nathalie Hinfray, Olivier Palluel, Benjamin Piccini, Wilfried Sanchez, Selim Ait-Aissa, et al.. Endocrine disruption in wild populations of chub (Leuciscus cephalus) in contaminated French streams. Science of the Total Environment, 2010, 408 (9), pp.2146-2154. 10.1016/j.scitotenv.2010.01.003 . ineris-00961748

\section{HAL Id: ineris-00961748 \\ https://hal-ineris.archives-ouvertes.fr/ineris-00961748}

Submitted on 20 Mar 2014

HAL is a multi-disciplinary open access archive for the deposit and dissemination of scientific research documents, whether they are published or not. The documents may come from teaching and research institutions in France or abroad, or from public or private research centers.
L'archive ouverte pluridisciplinaire HAL, est destinée au dépôt et à la diffusion de documents scientifiques de niveau recherche, publiés ou non, émanant des établissements d'enseignement et de recherche français ou étrangers, des laboratoires publics ou privés. 
ENDOCRINE DISRUPTION IN WILD POPULATIONS OF CHUB (LEUCISCUS

CEPHALUS) IN CONTAMINATED FRENCH STREAMS

HINFRAY Nathalie ${ }^{1^{*}}$, PALLUEL Olivier ${ }^{1}$, PICCINI Benjamin ${ }^{1}$, SANCHEZ Wilfried ${ }^{1}$, AÏTAÏSSA Selim ${ }^{1}$, NOURY Patrice ${ }^{2}$, GOMEZ Elena ${ }^{3}$, GERAUDIE Perrine ${ }^{4}$, MINIER Christophe $^{4}$, BRION François ${ }^{1}$, PORCHER Jean-Marc ${ }^{1}$

${ }^{1}$ Unité d'écotoxicologie, Institut National de l'Environnement Industriel et des Risques (INERIS), Verneuil-en-Halatte, France

${ }^{2}$ Laboratoire d'Ecotoxicologie, CEMAGREF, Lyon, France

${ }^{3}$ UMR 5569 CNRS - IRD - UMI - UMII 5569 « Hydrosciences », Département Sciences de l'Environnement et Santé Publique - Faculté de Pharmacie, Montpellier, France

${ }^{4}$ LEMA; UPRESS-EA 3222; IFRMP 23, GDR Ifremer IMOPHYS, Université du Havre, Le Havre, France

\section{* Correspondence and reprint requests:}

Dr. N. Hinfray

Institut National de l'environnement industriel et des risques (INERIS), Direction des Risques Chroniques, Unité d'évaluation des risques écotoxicologiques, Parc Technologique Alata, BP 2, 60550 Verneuil-en-Halatte, France

Phone : +33-3 44556969

Fax : +33-3 44556605

Email : nathalie.hinfray@ineris.fr 
The aim of this study was to assess endocrine disruptive effects in wild population of fish in five French rivers selected to represent different pollution contexts at two seasons (summer and fall). For that purpose, a panel of biometrical parameters (length, weight, gonado-somatic index: GSI) and biochemical (ethoxyresorufin-O-deethylase: EROD, vitellogenin: VTG, brain aromatase) and histological biomarkers (gonads histology) was used in chub (Leuciscus cephalus), a common cyprinid fish species. In fish from the reference site, EROD activity and VTG levels were low at the two seasons. Brain aromatase activities (AA) were similar to other species and increased with increasing GSI and gonad maturation. Among the four contaminated sites, the Jalle d'Eysines River was the most impacted site. At this site, fish were exposed to estrogenic substances as demonstrated by the VTG induction in males and the arrest of development of the gonads that led to lower brain AA compared to fish from the reference site. In fish from other contaminated sites, EROD activity was induced as compared to fish from the reference site and some males had elevated concentrations of VTG. Moreover, the presence of aromatase inhibiting compounds was demonstrated in the sediments of three contaminated sites, even if the precise nature of contaminants is not known. This study provides new data concerning endocrine disruption in wild fish populations inhabiting French rivers and demonstrates that measurements of in vivo and in

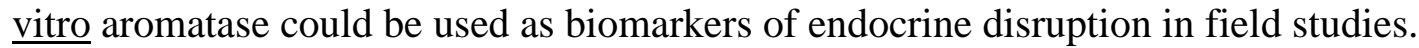

Key-words : endocrine disruption, chub, aromatase, vitellogenin, histology 


\section{Introduction}

It has now been clearly established that a number of chemical compounds and natural substances present in the aquatic environment are able to disturb the normal physiology and endocrinology of organisms (Arukwe and Goksoyr, 1998; Sumpter, 1998). These compounds are known as endocrine disrupting chemicals (EDCs) and are of different origins. Among them are natural and synthetic hormones, plant components, pesticides, compounds used in the plastic industry and in consumer products, as well as industrial by-products (Lavado et al., 2004). All these EDCs could enter the aquatic environment via effluents or surface runoff, and thus fish will inevitably be exposed. Several studies have documented reproductive disorders and/or endocrine effects in different species of fish exposed to sewage treatment works (STW) effluents or to pulp and paper mill effluents (Marshall Adams et al., 1992; Munkittrick et al., 1998; Karels et al., 1999; Hecker et al., 2002). However, the cause-effect relationship is difficult to establish due to the complexity of the endocrine system and the diversity of modes of action of the EDCs (Lister and Van Der Kraak, 2001).

Despite this complexity, a great number of studies have described endocrine disruption in fish from America, Canada, and Europe (for review see Jobling et al., 1998; Vos et al., 2000; Jobling and Tyler, 2003). Information on the status of French rivers regarding endocrine disruption is quite scarce. Studies showed the presence of estrogenic compounds in effluents (Balaguer et al., 1999) and the contamination of surface water and sediments by endocrine disrupters and more particularly estrogenic substances (Labadie and Budzinski, 2005; Pillon et al., 2005). In fish, estrogenic effects have been shown by induction of plasmatic vitellogenin (VTG) in wild males of stickleback ( $\underline{\text { Gasterosteus aculeatus) }}$ and chub (Leuciscus cephalus) sampled in rivers under urban pressure (Flammarion et al., 2000; Sanchez et al., 2008). Androgenic effects were also highlighted by the induction of spiggin in river under 
urban and industrialized pressure (Sanchez et al., 2008). However, these studies are scarce and to our knowledge, other alterations of the endocrine system have not been explored.

In this study, we investigated the potential alterations of the endocrine system and of the xenobiotic metabolism in wild fish from different French rivers, one reference and four contaminated sites that reflect different anthropogenic pressures (Table I). Chub (Leuciscus cephalus) was selected as a sentinel species due to its widespread distribution along the study areas and because it is a common non-migratory freshwater cyprinid species that inhabits both clean and polluted rivers (Flammarion and Garric, 1997). A set of biometrical measurements and biochemical biomarkers representing different biological functions were used to assess in situ impacts of EDCs in fish. Physiological parameters such as length, weight and gonad somatic index (GSI) were determined. Histological analysis of gonads was performed to determine the sex and the maturation state of the fish. The biochemical biomarkers included EROD activity (7-ethoxyresorufin-O-deethylase, a cytochrome P450 1A monooxygenase activity) a biomarker of exposure to AhR (Aryl Hydrocarbons receptor) ligands such as dioxins, polycyclic aromatic hydrocarbons (PAHs) and polychlorobiphenyls (PCBs) (Whyte et al., 2000), and plasmatic VTG in males, as a marker of exposure to xeno-estrogens (Flammarion et al., 2000). Vitellogenin is the yolk protein synthesized by the liver in females that serves as food reserve for the developing embryos. In male fish, very few, if any, vitellogenin can be detected. Although vitellogenin is normally not present in male fish, its synthesis can be easily induced by estrogens in laboratory experiments (Brion et al., 2002) and be used as a biomarker of estrogenic exposure in field studies (Sumpter and Jobling, 1995; Flammarion et al., 2000). Additionally, the activities of brain cytochrome P450 aromatase, a key steroidogenic enzyme responsible for the irreversible conversion of androgens to estrogens, were also measured in male and female fish. It is now known that EDCs can affect aromatase expression and/or activity through different modes of action 
(Cheshenko et al., 2008, Hinfray et al., 2008). The positive estrogenic regulation of brain aromatase cyp19a1b gene expression in different fish species is well demonstrated (Callard et al., 2001; Menuet et al., 2005; Hinfray et al., 2006b), this up-regulation requiring binding of liganded-ER on ERE located in the promoter region of the gene (Menuet et al., 2005). On the contrary, several classes of compounds such as dioxin-like compounds, organotins or imidazole-like fungicides have been shown to interfere negatively either with the aromatase gene expression or the aromatase enzymatic complex to inhibit aromatase activity (Monod et al., 1993; Sanderson et al., 2002; Hinfray et al., 2006a; Laville et al., 2006, Cheshenko et al., 2007). Perturbations of aromatase activities have also been reported in wild fish populations living in contaminated areas (Noaksson et al., 2001; Orlando et al., 2002; Lavado et al., 2004; Hecker et al., 2007). Additionally, the aromatase-inhibiting potency of sediments extracts

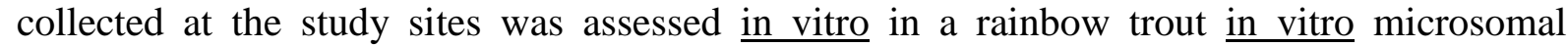
aromatase activity assay previously developed in our laboratory (Hinfray et al., 2006a). To achieve this goal, we first developed the VTG and the aromatase activity assays for chub and checked their responsiveness and sensitivity after exposure to a model compound, ethinylestradiol. Our aims were (i) to acquire data on endocrine disruption in male and female fish from reference and contaminated French rivers, (ii) to assess pathways of endocrine disruption other than VTG synthesis perturbations to extend fish exposure assessment to non estrogenic substances, (iii) to determine the extent to which aromatase could be a sensitive biomarker for field studies. 
Materials and methods

\section{Laboratory exposure to EE2}

To validate chub VTG and aromatase activity assays, we exposed fish to a model endocrine disrupting compound, ethynilestradiol (EE2), as a typical inducer of VTG synthesis and brain aromatase activities.

24 adult wild chubs were collected in September 2007 from two different moderately contaminated sites under urban and agricultural pressure. Fish were maintained in the laboratory for 2 months in clear water for depuration.

Two groups of 12 fish were randomly held in two glass aquaria filled with $200 \mathrm{~L}$ of water. They were fed a commercial pellet diet everyday (about $1 \%$ total body weight). After an acclimatation period of 4 days, they were exposed to EE2 (nominal concentration of $50 \mathrm{ng} / \mathrm{L}$ in DMSO) or DMSO alone $(0.01 \% \mathrm{v} / \mathrm{v})$ in water for 21 days. The exposure was carried out in semi-static conditions and $150 \mathrm{~L}$ of water was renewed every day. Photoperiod was $16 \mathrm{~h}$ night- $8 \mathrm{~h}$ day. Physicochemical parameters were measured each day (temperature $16.9 \pm 0.6$ ${ }^{\circ} \mathrm{C} ; \mathrm{pH} 8.0 \pm 0.2$; dissolved oxygen $7.7 \pm 0.4 \mathrm{mg} / \mathrm{L} ;$ conductivity $316 \pm 34 \mu \mathrm{S} / \mathrm{cm}$ [mean \pm $\mathrm{SD}])$.

\section{Sampling of wild fish}

Male and female wild chub were collected by electrofishing in five different French rivers in summer (May/June) and fall (September/October) 2006. According to Guerriero et al. (2005), for common chub these periods correspond to spawning and post-spawning periods respectively. The sampling stations were characterized by different environmental influences (industrialized, urban, agricultural pressures) and are described in the Table 1. 


\section{Tissues sampling}

Dissection was carried out immediately after the fish were caught. A blood sample was taken directly from the caudal vein using a heparinised syringe. Blood samples were centrifuged for 10 min $\left(3000 g, 4^{\circ} \mathrm{C}\right)$ and the plasma were stored at $-80^{\circ} \mathrm{C}$ until VTG analysis. Total body length $(\mathrm{cm})$, body weight $(\mathrm{g})$ and macroscopic sex were recorded for each individual. The gonado-somatic index (GSI = gonad weight expressed as a percentage of total body weight) was calculated for each fish. Small pieces of liver were removed, placed in $2 \mathrm{ml}$ tubes with glass grinding balls containing phosphate buffer ( $\mathrm{pH}$ 7.6) and snapped frozen in liquid nitrogen before storage at $-80^{\circ} \mathrm{C}$ until EROD activity analysis. Gonads were removed and fixed in formaldehyde (4\%) until histological analysis. Brains were sampled and homogenized with a Teflon potter homogenizer in a $50 \mathrm{mM}$ potassium phosphate buffer, $\mathrm{pH}$ 7.4, containing $1 \mathrm{mM}$ PMSF, $1 \mathrm{mM}$ EDTA and $20 \%$ glycerol $(\mathrm{v} / \mathrm{v})$ in a ratio of 1:2(w/v). The homogenates were then frozen in liquid nitrogen and stored at $-80^{\circ} \mathrm{C}$ until aromatase activity (AA) analysis.

\section{EROD activity assay}

Frozen livers were homogenized for 2 x 10 seconds with an automated grinding ball homogeniser (Precellys ${ }^{\circledR}$ 24, Bertin Technologies, France). The homogenates were centrifuged $\left(10,000 \mathrm{~g}, 15 \mathrm{~min}, 4{ }^{\circ} \mathrm{C}\right)$ to obtain the post-mitochondrial (S9) fraction. Total protein concentrations of these fractions were determined using bovine serum albumin (Sigma-Aldrich, France) as a standard (Bradford, 1976). EROD assay was adapted from (Flammarion et al., 1998) with minor modifications for substrate concentrations. Briefly, 10 $\mu 1$ of diluted liver S9 fraction were added to $200 \mu$ l of 7 -ethoxyresorufin $(8 \mu \mathrm{M}$ final concentration) and $10 \mu \mathrm{l}$ of $\beta-\mathrm{NADPH}(0.5 \mathrm{mM}$ final concentration) to start the reaction. 
Fluorescence kinetics were measured in a black microplate with a spectrofluorimeter (Safire², Tecan, Austria).

\section{Chub VTG assay}

A homologous competitive ELISA assay was specifically developed to quantify VTG in chub plasma. For that purpose, VTG was purified from E2-induced chubs according to Brion et al. (2000) and polyclonal anti-chubVTG antibodies were raised in rabbits as previously described (Brion et al., 2002). Specificity of the anti-chubVTG antibodies was verified and an homologous chub VTG competitive ELISA assay was developed and validated according to Brion et al. (2002). Briefly, Nunc Maxisorp microtiter plates (Nunc Roskilde, Denmark) were coated with $100 \mu \mathrm{L}$ of Chub-Vtg at $100 \mu \mathrm{g} / \mathrm{ml}$ in $0.05 \mathrm{M}$ carbonate-bicarbonate (pH 9.6). Standard of Vtg was serially half-diluted from 0.98 to $1000 \mathrm{ng} / \mathrm{ml}$, and plasma samples were serially third-diluted five times from an initial dilution of 1:7.5 for males and 1:25 for female. Standards and plasma samples were preincubated with the primary antibody (final dilution of 1:80000 in PBS, 1\% BSA). Pre-coated ELISA microplates were incubated with preincubated primary antibody solution with standards or samples $(100 \mu 1)$ and then with secondary antibody (horseraddish peroxidase goat anti-rabbit IgG diluted 1:2000 in PBS, 1\% BSA). The peroxidise activity was revealed by adding $100 \mu 1$ of tetramethylbenzidine enzyme substrate (Kirkegaard and Perry Laboratories, Gaithersburg, MD, USA) and was stopped by addition of $50 \mu \mathrm{l}$ of $1 \mathrm{M}$ phosphoric acid $\left(\mathrm{H}_{3} \mathrm{PO}_{4}\right)$. The absorbance was read at $450 \mathrm{~nm}$. Calculation was performed as described by Brion et al. (2002).

\section{Brain aromatase activity assay}


Brain homogenates were centrifuged $\left(10,000 \mathrm{~g}, 20 \mathrm{~min}, 4{ }^{\circ} \mathrm{C}\right)$ to obtain $\mathrm{S} 9$ fractions. Total protein concentrations of the $\mathrm{S} 9$ fractions were determined using bovine serum albumin (Sigma-Aldrich, France) as a standard (Bradford, 1976).

The AA was measured as the specific release of tritiated water accompanying the conversion of $\left[1 \beta-{ }^{3} \mathrm{H}(\mathrm{N})\right]$ androstenedione to estrone as described in Hinfray et al. (2006a) with some modifications. Indeed, optimal conditions to measure chub brain AA were first determined, including duration and temperature of incubation, concentration of S9 protein, and concentration of labeled substrate.

Briefly, $500 \mu \mathrm{g}$ of brain $\mathrm{S} 9$ protein were added to a potassium phosphate buffer $(50 \mathrm{mM})$

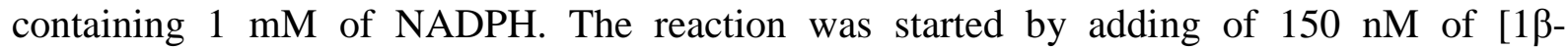
$\left.{ }^{3} \mathrm{H}(\mathrm{N})\right]$ androst-4-ene-3,17-dione. After $1 \mathrm{~h}$ at $18^{\circ} \mathrm{C}$ the reaction was stopped and the aqueous fraction was extracted twice with chloroform and once with charcoal (5\% w/v) to remove any remaining organic compounds. Then, the radioactivity of the aqueous fraction was read in a Liquid Scintillation Counter (Microbeta, Perkin Elmer).

The aromatase assay was demonstrated to be linear with time and the amount of protein. Appropriate background and control incubations were routinely performed.

\section{Gonad histology}

After fixing the gonads in formaldehyde $4 \%$, three pieces of the gonad were dehydrated through a series of graded ethanol, cleared with toluene and embedded in paraffin. Sections were $7 \mu \mathrm{m}$ thick, stained with haematoxylin-eosin-saffron, and observed under an optical microscope.

Ovarian maturation was divided into three stages: primary oocytes (only oogonia and primary oocytes), early vitellogenic stage (primary oocytes, and secondary oocytes), and advanced vitellogenic stage (a great majority of secondary oocytes). Testicular maturation was also 
divided into three stages according to the predominant cell type in the testis: spermatogonies, spermatocytes and spermatozoids stages. None of the fish testes studied presented a majority of spermatids.

\section{In vitro analysis of sediments extracts}

Sediments were sampled in the upper $10 \mathrm{~cm}$ surface layer (about $500 \mathrm{~g}$ ), sieved using a $2 \mathrm{~mm}$ sieve and stored at $-20^{\circ} \mathrm{C}$ until processing. Extraction of 5 grams of dry sediment was performed by Accelerated Solvent Extraction (ASE) according to Louiz et al. (2008). The solvent used for ASE was a heptane:acetone (1:1) mixture. The final extract was dissolved in methanol.

The presence of aromatase inhibiting compounds in sediments extracts was assessed by using an in vitro aromatase assay previously developed (Hinfray et al., 2006a). Sediment extracts $(0.25 \%)$ were pre-incubated with rainbow trout (rt) brain microsomes during $1 \mathrm{~h}$ at $27^{\circ} \mathrm{C}$ in a potassium phosphate buffer $(50 \mathrm{mM})$ containing $1 \mathrm{mM} \mathrm{NADPH}$. The aromatization reaction was then started by the addition of $75 \mathrm{nM}$ of $\left[1 \beta^{3} \mathrm{H}(\mathrm{N})\right]$ androst-4-ene-3,17-dione. After 30 min, the reaction was stopped. The aqueous fraction was extracted and the radioactivity was read as described above for chub brain AA. Three independent experiments were performed for each sediment extract.

\section{Statistical analysis}

Statistical analyses were performed with SPSS software (SPSS Inc, Chicago IL, USA). Data of EROD activity, VTG synthesis and in vivo AA were subjected to a logarithmic transformation to stabilize the variance and obtain a normal distribution. We verified that $\log (1+$ data) followed a normal distribution (Khi2 test for normality, $\mathrm{p}<0.05)$ and that variance was homogeneous (Levene's test, $\mathrm{p}<0.05$ ). Data sets exhibiting normal distribution 
after $\log$ transformation were subjected to a one-way analysis of variance (ANOVA) using

244 sites as factor followed by a Tuckey's test $(\mathrm{p}<0.05)$. Data sets with no normal distribution were subjected to a non parametric test of Kruskall-Wallis followed by a Mann-Whitney test $(\mathrm{p}<0.05)$. Males and females were treated separately.

247 For gonad stage of development analysis, differences of proportions between the reference 248 site and the contaminated sites were elucidated by the Fisher's test $(\mathrm{p}<0.05)$.

The effects of sediment extracts on in vitro AA were expressed as a percentage of the solvent control AA. Due to small number of assays $(\mathrm{N}=3)$, statistical analysis was performed using the Student's t test $(\mathrm{p}<0.05)$. 


\section{Laboratory exposure to EE2}

Analysis of biometric parameters of male chub exposed to $50 \mathrm{ng} / \mathrm{L}$ EE2 for 21 days revealed no difference compared to the control males, while exposed females had lower length, weight and GSI values when compared to the control females (Table 2). In control chub, VTG concentrations ranged between 500 and $8400 \mathrm{ng} / \mathrm{ml}$ for males and between 0.6 and $25 \mu \mathrm{g} / \mathrm{ml}$ for females. Exposure to EE2 induced VTG synthesis around 13000 and 7500 fold in males and females, respectively (Table 3). Concentrations of VTG in EE2 exposed fish get from 23243 to $36128 \mu \mathrm{g} / \mathrm{ml}$. Brain AA were also induced by exposure to EE2. Brain AA were about 4-fold and 2.6-fold higher in exposed males and females chub respectively compared to control chubs (Table 3). EROD activities were strongly inhibited in both male and female chubs (Table 3). Overall, these results showed the suitability of the biochemical assays established for chub and the responsiveness of this fish species to a model EDC.

\section{Field study}

\section{Morphometrical parameters}

The main morphometric characteristics of chub collected in the different study sites are given in Table 4. Male and female fish from the Drôme River (reference site) had lower GSI values in fall than in summer. All the fish from the contaminated sites exhibited similar values of GSI in summer and fall, except female fish from the Nonette River that exhibited higher GSI values in fall. 
Males collected in the summer were homogeneous in size and weight; however, fish from all contaminated sites presented lower GSI values as compared to fish from the reference site (Drôme). During the fall, males caught in all contaminated sites were longer and heavier than those from the Drôme River, but only males from the Nonette River had higher GSI values. For females collected in the summer, only those from the Rhône and Jalle d'Eysines rivers were different from the reference site (Drôme). They had higher size and weight but lower GSI values. In the fall, females from the Rhône and the Nonette rivers were longer and/or heavier than females from the Drôme River. Additionally, females from the Jalle d'Eysines River showed lower GSI values and females from the Nonette river showed higher GSI values compared to females from the reference site.

\section{$\underline{\text { Histological analysis }}$}

Females caught in the reference site were mainly at the advanced vitellogenesis stage in the summer (Figure 1A). In the fall, females were at the primary oocyte stage (33\%) and early vitellogenic stages $(67 \%)$ (Figure 1B). Males sampled in the summer in the reference site were all mature (spermatozoids stage) (Figure 1C). In the fall, all males had gonads at the spermatogonies or spermatocytes stages (Figure 1D). In the reference site, fish were clearly at different stages of gonad development between summer and fall.

In the summer, all contaminated sites, except the Jalle river, had a majority of females in vitellogenesis (early or advanced vitellogenesis) (Figure 1A). On the contrary, females from the Jalle d'Eysines River were predominantly at the primary oocyte stage. In the fall, females were essentially at the primary oocytes stage in the Jalle d'Eysines River while females from the three other contaminated sites had a high proportion of advanced vitellogenic stages (Figure 1B). The arrest of gonad development in fish from the Jalle d'Eysines River in the summer and the fall is in agreement with the lower GSI observed in these fish. 
In the contaminated sites, males displayed high proportions of testis at the spermatogonies and spermatocytes stages in summer (Figure 1C). In the fall, they presented testis at the spermatogonies or spermatocytes stages (Figure 1D).

Fish from all sites were also examined for the presence of intersex characteristics. Intersex fish were found in only two sites: the Drôme (reference site) and the Rhône rivers. In the summer in the Drôme River, 13\% (2/15) of males were intersex with one male with more than 10 primary oocytes per slide and one male with only one primary oocyte in one slide. No intersex fish were found in the Drôme River during fall. In the Rhône River, 9\% (1/11) and $7 \%(1 / 15)$ of males were intersex in the summer and the fall respectively. All of them presented more than 10 primary oocytes per slide. In the three other sites, no intersex fish were found during either season.

\section{EROD activity}

Mean EROD activities measured in male and female chubs from the Drôme River were comprised between 0.2 and $2.1 \mathrm{pmol} / \mathrm{mg} / \mathrm{min}$ (Figure $2 \mathrm{~A}$ and $\mathrm{B}$ ). These values are lower but comparable to those measured in Chub from other French unpolluted rivers (2-9 $\mathrm{pmol} / \mathrm{mg} / \mathrm{min}$ ) (Flammarion and Garric, 1997). In summer, EROD activity was induced in male and female from the Jalle d'Eysine and the Nonette rivers and in females from the Lez river compared to fish from the reference site (Drôme), suggesting an exposure of fish to AhR agonists (Figure 2A and B). The induction factors were comprised between 4 (males from the Jalle d'Eysine river) and 18.7 (females from the Jalle d'Eysine River). In fall, only males from the Nonette River exhibited higher EROD activity than fish from the Drôme River (Figure 2A). No difference was noted for females during the fall. It is interesting to note that EROD activity in females exhibited high inter-individual variations, probably due to the an 
influence of GSI on EROD activity in females as previously noted by Flammarion et al. (1998).

\section{$\underline{\text { Plasmatic VTG }}$}

In the reference site (Drôme river), males exhibited plasmatic VTG concentrations from non detectable levels to $382 \mathrm{ng} / \mathrm{ml}$ (Figure 3). Geometric mean plasmatic VTG concentrations were of $93 \mathrm{ng} / \mathrm{ml}$ and $76 \mathrm{ng} / \mathrm{ml}$ in the summer and the fall respectively. VTG concentrations measured in our study are of the same order as those measured in male cyprinid fish from reference sites such as roach (mean concentrations between 47 and $1502 \mathrm{ng} / \mathrm{ml}$ ) (Tyler et al., 2005) but slightly lower than those measured in chub (mean concentration of $970 \mathrm{ng} / \mathrm{ml}$ ) (Randak et al., 2009). Only the males from the Jalle d'Eysines River presented statistically significant induced mean VTG concentrations in summer as compared to males from the reference site, with levels of VTG comprise from $82 \mathrm{ng} / \mathrm{ml}$ to $8663 \mathrm{ng} / \mathrm{ml}$. In all contaminated sites, mean VTG levels were not statistically different, but some males showed elevated concentrations of VTG compared to males from the reference site that can reach $49 \mu \mathrm{g} / \mathrm{ml}$, corresponding to level of VTG found in females in control laboratory experiment (Figure 3). Nevertheless, these induced VTG concentrations measured from field chub are lower than those measured in males exposed to $50 \mathrm{ng} / \mathrm{L}$ EE2 during 21 days (Table 3).

\section{$\underline{\text { Brain aromatase activity }}$}

In the reference site, high AA was measured in the brain of male and female fish without any difference between sexes in the two seasons. This brain AA varied as maturity of the gonads progresses (Figure 4). In females, brain AA was higher during vitellogenesis as compared to the primary oocytes stage. Despite the variations of AA in females according to the stage of development of the gonads, no difference between seasons was observed in female brain AA 
(Figure 5). In males from the reference site, brain AA was higher in fish with testis full of spermatozoids (only in summer) as compared to testis at the spermatogony/spermatocyte stages (only in fall) (Figure 4). As a result, a significant effect of the season was noted on brain AA in males with higher AA in the summer than in the fall (Figure 5). At the contaminated sites, brain AA was inhibited in males from the Rhône and Jalle d'Eysines rivers in the summer as compared to brain AA of males from the Drôme river (Figure 5). These brain AA inhibitions led to the suppression (Rhône river) or the inversion (Jalle d'Eysines river) of the seasonal effect on brain AA in the fish from these two sites. No significant effect of site and season was found in female brain AA.

\section{Effect of sediments extracts on in vitro aromatase activity}

Sediment extracts of three sites (Rhône, Jalle d'Eysines and Nonette) at the two seasons significantly inhibited in vitro brain AA (between $42 \%$ and $76 \%$ of inhibition) indicating the presence of aromatase inhibitors in sediments (Figure 6). No effect was detected at the Lez and Drôme sites. 


\section{Methodological developments}

In this study, a specific homologous competitive chub-VTG ELISA assay and an aromatase

372 activity assay were first developed and used to assess the effect of a low concentration of ethinylestradiol (EE2). As expected, exposure to $50 \mathrm{ng} / \mathrm{L}$ EE2 led to a tremendous VTG synthesis in chub (about $10^{4}$ induction factor). Cyprinid fish such as chub, roach or zebrafish have previously been shown to be sensitive to estrogens exposure (Flammarion et al., 2000; Brion et al., 2004; Lange et al., 2008; Zlabek et al., 2009). In our study, VTG concentrations in exposed males and females reached more than $1 \mathrm{mg} / \mathrm{ml}$ supporting similar results observed for chub (Flammarion et al., 2000). It is also interesting to note that the plasmatic VTG concentrations measured in control males from the EE2 exposure experiment $(2.1 \mu \mathrm{g} / \mathrm{ml})$ were clearly higher than those of males from reference sites (Drôme river in our study: 93.2 $\mathrm{ng} / \mathrm{ml}$ in summer and $76.1 \mathrm{ng} / \mathrm{ml}$ in fall; reference site in the study of Randak et al. (2009): $970 \mathrm{ng} / \mathrm{ml}$ ), indicating that even after two months depuration in clean water, VTG concentrations of chubs used as control for the EE2 exposure were not returned to levels found in fish from non contaminated sites. Moreover, brain AA was also induced after exposure to EE2. It is now well demonstrated that brain aromatase cyp19a1b is an estrogenregulated gene in different fish species (Callard et al., 2001; Menuet et al., 2005; Hinfray et al., 2006b), its up-regulation requiring the binding of liganded-ER with ERE and 1/2 ERE located in the promoter region of the gene (Menuet et al., 2005). Although, to date the chub cyp19a1 genes were not sequenced, our results strongly suggest that chub possess a cyp19a1b gene which is positively regulated by (xeno)-estrogens.

\section{Field study}


In this study, potential alterations of the endocrine system of wild chub were investigated by using a multi-parametric approach including morphological parameters (length, weight, GSI, gonad histology) and biochemical biomarkers (EROD, VTG, AA). We first looked at all these parameters in fish from the Drôme River to confirm the reference status of this site.

\section{The reference site}

The Drôme River in Saillans was chosen as the reference site since it was located in a relatively clean area. Previous studies on PCB and heavy metals concentrations in fish and in sediments showed that the Drôme river is one of the least polluted French river (Flammarion and Garric, 1997; Mazet et al., 2005).

As expected, GSI of male and female chub were higher in the summer than in the fall. The GSI well reflected the histological state of the gonads. Female chubs were in full vitellogenesis and male chubs were full of spermatozoids in the summer which correspond to the reproductive period for this species (Guerriero et al., 2005). In the fall, the post spawning period for chub, male and female gonads were at early stages of development. Thus, chub from the Drôme River showed a normal gonadal development. Nevertheless, among male chubs from the Drôme River, the incidence of intersex was $13 \%$. Intersex fish prevalence observed in wild cyprinid fish population sampled in reference sites are comprised between 0 and $41 \%$ for chub, roach and gudgeon with a lower susceptibility of chub compared to other species (Flammarion et al., 2000; Minier et al., 2000; Van Aerle et al., 2001; Jobling et al., 2002; Bjerregaard et al., 2006; Randak et al., 2009). Indeed, in our study, prevalence of intersex fish did not allow for discrimination between unpolluted and polluted sites.

Brain AA of males and females chub from the Drôme river were of the same order as brain AA measured in other wild fish species such as perch and roach (Noaksson et al., 2001) and bream (Hecker et al., 2007). In our study, the brain AA fluctuated with the stage of maturity of the gonads (histological examination). Indeed, brain AA of male and female increased with 
maturation and when GSI increased during the reproductive period. Such fluctuations in brain AA during the reproductive cycle were also observed in goldfish, sea bass, rainbow trout, perch and roach suggesting an increase need of estrogens in the brain during reproduction (Pasmanik and Callard, 1988; Noaksson et al., 2001; Gonzalez and Piferrer, 2003; Hinfray et al., 2006a). It has been suggested that AA (and production of estrogens) in the male brain during the reproductive period could be associated with sexual behavior of fish (Schlinger et al., 1999; Hallgren et al., 2006). In males and females, brain AA may also be linked to the secretion of gonadotropin hormones known to be involved in gonadal growth and maturation, and spermiation/ovulation (Rosenfeld et al., 2007). Nonetheless, these brain AA fluctuations during the reproductive cycle should be kept in mind to determine the optimal time-point for employing this parameter as a biomarker of endocrine disruption.

\section{The contaminated sites}

Among the contaminated sites of our study, the most impacted was the Jalle d'Eysines River. Males from the Jalle d'Eysines River exhibited statistically significantly induced plasmatic VTG levels compared to males from the reference site. Contamination of the Jalle d'Eysines River by steroidal hormones have previously been shown (Labadie and Budzinski, 2005). The authors showed that levels of estrogens in this river in 2003-2004 could reach $30 \mathrm{ng} / \mathrm{L}$ for estrone, $1.2 \mathrm{ng} / \mathrm{L}$ for estradiol and $1 \mathrm{ng} / \mathrm{L}$ for estriol. Here we provide evidence that fish from this site were affected by xeno-estrogens and it would be advisable to determine whether these steroidal estrogens are responsible for the VTG inductions. In both male and female chub from the Jalle d'Eysines River, an arrest of the gonadal development was observed. Females from this site exhibited lower GSI compared to females from the Drôme River in both seasons. Histological examination of these fish revealed that more than $70 \%$ of the females were at the primary oocytes stage during summer and fall. Concerning males of the Jalle d'Eysines River, a great proportion (70\%) were at the spermatogonies stage in the 
summer, as reflected by the lower GSI and the lower brain AA observed, compared to those of males from the Drôme river. As previously shown for zebrafish and fathead minnow, laboratory exposure to estrogenic substances lead to reduction in GSI and inhibition of gonad development (Jobling et al., 1996; Miles-Richardson et al., 1999; Fenske et al., 2005). Thus, our results on VTG and gonads development are consistent with an estrogenic exposure of fish in the Jalle d'Eysines River.

Given the up-regulation of brain AA by exposure to EE2 (Table 2), an increase of brain AA would have been expected in fish from the Jalle d'Eysines river. The absence of brain AA increase might be due to xeno-estrogens concentrations in the surface water of the Jalle d'Eysines River that are too low to induce brain AA. Nevertheless, all chub used for the laboratory EE2 exposure were at early reproductive stages (primary oocyte and spermatogonia stages) with basal brain AA lower than that of the chub caught during the summer and the fall in the Jalle d'Eysines River, and thus probably allowing greater inducibility of brain AA. Moreover, males caught in the summer in the Jalle d'Eysines River exhibited lower brain AA than fish from the reference site. This is well in agreement with the predominance of males at early stages of gonad development, for which brain AA are low compared to later stages (Figure 4). Indeed, when brain AA of males was classified according to the gonad stage of development, no difference was observed between males from the Jalle d'Eysines River and those from the reference site (data not shown). All these results indicate that the inhibition of male brain AA in summer in the Jalle d'Eysines River reflects the arrest of gonad development instead of a direct effect on the aromatase expression/activity, demonstrating that brain AA perturbations could be indicative of a reproductive disorder.

In the Nonette and the Lez rivers, chub brain AA was not affected at any season. On the contrary, brain AA of males caught in summer from the Rhône River was lower than those of males from the Drôme River at the same season. However, only males exhibited lower brain 
AA, not females. Compared to males from the Drôme River, a great proportion of males from the Rhône River were at the spermatogonies or spermatocytes stages in summer, suggesting a delay in testis maturation. Nevertheless, it should be noted that fish from the Rhône River were caught mid-May while fish from the Drôme River were caught mid-June, thus introducing a potential bias. As we have previously shown, brain AA was lower in males at the spermatogonies and spermatocytes stages compared to that of males at the spermatozoids stage. Even if the most likely explanation for having lower brain AA in males from the Rhône river might be related to the testis maturation stage of these fish, the possibility that fish were exposed to aromatase inhibiting substances could not be dismissed. The presence of aromatase inhibiting compounds in surface sediments extracts of the Rhône, the Jalle d'Eysines and the Nonette rivers was demonstrated by using an in vitro aromatase assay previously developed in the laboratory (Hinfray et al., 2006a). Pesticides (more particularly imidazole-like pesticides), flavonoids or PBDEs have been shown to inhibit AA in vitro in different microsomal systems (Pelissero et al., 1996; Le Bail et al., 2000; Hinfray et al., 2006a; Canton et al., 2008). However, the precise nature of the contaminants present in sediments and their potential bioavailability to fish are not known.

Previous studies also showed in vivo perturbations of the endocrine system including inhibitions of brain AA in wild fish living in contaminated areas. In Sweden, a great number of wild female perch (Perca fluviatilis) exposed to effluents from a public refuse dump were showed to be sexually immature and this was associated with an inhibition of brain AA, decreased GSI and reduced levels of steroids (Noaksson et al., 2001). Similar observations were made in bream (Abramis brama) where fish exposed to various industrial effluents (including (agro)chemical and petrochemical plants) presented inhibited brain AA, decreased GSI, and lower VTG and steroids concentrations (Hecker et al., 2007). In our study, some males in the Nonette and the Lez rivers presented induction of plasmatic VTG concentrations 
as compared to males from the reference site suggesting a slight exposure of fish to estrogenic substances. However, there was a large variability between males collected in one site since VTG concentrations varied from non detectable up to $49 \mu \mathrm{g} / \mathrm{ml}$. Such great intra-site variability in plasmatic VTG concentrations was previously observed by Jobling et al. (1998) and Flammarion et al. (2000) in studies on roach and chub respectively.

In the Nonette River, chub also exhibited strong EROD activity inductions in the two seasons. EROD activities are known to respond to AhR agonists such as dioxins, PCBs, PAHs and some pesticides (Whyte et al., 2000). Interestingly, very strong dioxin-like activity was found in sediment extracts of this site in in vitro assays using PLHC-1 cells (data not shown), indicating the presence of $\mathrm{AhR}$ agonists in the water and sediments of the Nonette river even though the precise nature of the substances was not determined. In fish, AhR agonistic compounds such as dioxins, PAHs or beta-naphtoflavone can negatively affect the estrogendependent genes expression in the liver, such as ER $\alpha$ and VTG, both $\underline{\text { in vitro }}$ and in vivo (Navas and Segner, 2000, Bemanian et al., 2004, Aubry et al. 2005). The negative interaction of AhR agonistic compounds on the estrogenic signaling pathway likely explain the significant negative correlation between EROD activity and VTG synthesis $\left(\mathrm{R}^{2}=0.565\right.$; $\mathrm{p}<0.05)$ which was found in fish from the Nonette River. As a consequence, the presence of AhR agonistic compounds at this site might have led to an under-estimation of the estrogenic contamination level due to interfering effects of AhR agonists also present at this site.

Previous field studies in France mainly focused on VTG as marker of endocrine disruption (Flammarion et al., 2000; Sanchez et al., 2008). However, evidence shows that several chemicals (alone or in mixture) can act at multiple targets to disrupt physiological functions in fish. Indeed, in fish from the Jalle d'Eysines River, we showed at the same time perturbations of plasmatic VTG synthesis, of in vivo brain AA and alterations of gonads development. Considering the complex exposure scenario in field studies it seems difficult to assess 
endocrine perturbations with a unique biomarker. Thus, more comprehensive molecular/biochemical approaches are needed to identify pathways of endocrine disruption.

\section{Conclusion}

This study provides evidence of endocrine disruption in fish from French rivers. The biomarkers used in our study allowed for the detection of perturbations in diverse tissues (liver, brain, gonads) and of EDCs in sediments. In the four contaminated sites, at least one biomarker was disturbed, suggesting the contamination of fish and/or sediments and underlining the importance of assessing effects on different physiological targets. However, it remains to determine which substances are responsible for the effects observed. For that purpose, a combination of biotesting, fractionation procedures and chemical analytical methods, also named Effect Directed Analysis, could be used (Brack, 2003). Moreover, aromatase proved to be a promising biomarker of endocrine disruption in field studies, by combining in vitro and 스 vivo measurements to detect contamination by aromatase inhibiting substances in sediments and fish. Finally, it could be interesting to use this multiparametric approach to assess endocrine disruption in a larger number of sites.

\section{Acknowledgements}

This research was funded by the French Ministry of Ecology and Sustainable Development (National Program of Research on Endocrine Disrupters). We thank all the researchers, technicians and students who have kindly contributed to the collection of samples. We are also grateful to the French National Agency for Water and Aquatic Environments for their technical support for the sampling of fish 


\section{References}

Arukwe A, Goksoyr A. Xenobiotics, xenoestrogens and reproduction disturbances in fish. 1999; 233: 47-56.

552

Bjerregaard LB, Korsgaard B, Bjerregaard P. Intersex in wild roach (Rutilus rutilus) from Danish sewage effluent-receiving streams. Ecotoxicol Environ Saf 2006; 64: 321-328. in complex mixtures? Anal Bioanal Chem 2003; 377: 397-407.

Bradford M. A rapid and sensitive method for the quantitation of microgram quantities of protein utilizing the principle of protein-dye binding. Anal Biochem 1976; 72: 248-254.

561

Brion F, Rogerieux F, Noury P, Migeon B, Flammarion P, Thybaud E, Porcher JM. Two-step purification method of vitellogenin from three teleost fish species: rainbow trout (Oncorhynchus mykiss), gudgeon (Gobio gobio) and chub (Leuciscus cephalus). J Chromatogr B Biomed Sci Appl 2000; 737: 3-12. 
Brion F, Nilsen BM, Eidem JK, Goksoyr A, Porcher JM. Development and validation of an enzyme-linked immunosorbent assay to measure vitellogenin in the zebrafish (Danio rerio). Environ Toxicol Chem 2002; 21: 1699-708.

Brion F, Tyler CR, Palazzi X, Laillet B, Porcher JM, Garric J, Flammarion P. Impacts of 17[beta]-estradiol, including environmentally relevant concentrations, on reproduction after exposure during embryo-larval-, juvenile- and adult-life stages in zebrafish (Danio rerio). Aquat Toxicol 2004; 68: 193-217.

Callard GV, Tchoudakova AV, Kishida M, Wood E. Differential tissue distribution, developmental programming, estrogen regulation and promoter characteristics of cyp19 genes in teleost fish. J Steroid Biochem Mol Biol 2001; 79: 305-314.

Canton RF, Scholten DEA, Marsh G, De Jong PC, Van Den Berg M. Inhibition of human placental aromatase activity by hydroxylated polybrominated diphenyl ethers (OH-PBDEs). Toxicol Appl Pharmacol 2008; 227: 68-75.

Cheshenko K, Brion F, Le Page Y, Hinfray N, Pakdel F, Kah O, Segner H, Eggen RI. Expression of Zebra Fish Aromatase cyp19a and cyp19b Genes in Response to the Ligands of Estrogen Receptor and Aryl Hydrocarbon Receptor. Toxicol Sci 2007; 96: 255-67.

Fenske M, Maack G, Schafers C, Segner H. An environmentally relevant concentration of estrogen induces arrest of male gonad development in zebrafish, Danio rerio. Environ Toxicol Chem 2005; 24: 1088-98. 
Flammarion P, Garric J. Cyprinids EROD activities in low contaminated rivers: A relevant statistical approach to estimate reference levels for EROD biomarker? Chemosphere 1997; 35: $2375-2388$.

Flammarion P, Migeon B, Garric J. Statistical analysis of cyprinid ethoxyresorufin-Odeethylase data in a large French watershed. Ecotoxicol Environ Saf 1998; 40: 144-53.

Flammarion P, Brion F, Babut M, Garric J, Migeon B, Noury P, Thybaud E, Palazzi X, Tyler CR. Induction of Fish Vitellogenin and Alterations in Testicular Structure: Preliminary Results of Estrogenic Effects in Chub (Leuciscus cephalus). Ecotoxicology 2000; 9: 127-135.

Gonzalez A, Piferrer F. Aromatase activity in the European sea bass (Dicentrarchus labrax L.) brain. Distribution and changes in relation to age, sex, and the annual reproductive cycle. Gen Comp Endocrinol 2003; 132: 223-230.

Guerriero G, Ferro R, Ciarcia G. Correlations between plasma levels of sex steroids and spermatogenesis during the sexual cycle of the chub, Leuciscus cephalus L. (Pisces : Cyprinidae). Zool Stud 2005; 44: 228-233.

Hallgren SLE, Linderoth M, Olsen KH. Inhibition of cytochrome p450 brain aromatase reduces two male specific sexual behaviours in the male Endler guppy (Poecilia reticulata). Gen Comp Endocrinol 2006; 147: 323-328. 
Hecker M, Tyler CR, Hoffmann M, Maddix S, Karbe L. Plasma biomarkers in fish provide evidence for endocrine modulation in the Elbe River, Germany. Environ Sci Technol 2002; 36: $2311-2321$.

Hecker M, Thomas Sanderson J, Karbe L. Suppression of aromatase activity in populations of bream (Abramis brama) from the river Elbe, Germany. Chemosphere 2007; 66: 542-552.

Hinfray N, Porcher JM, Brion F. Inhibition of rainbow trout (Oncorhynchus mykiss) P450 aromatase activities in brain and ovarian microsomes by various environmental substances. Comp Biochem Physiol C-Toxicol Pharmacol 2006a; 144: 252-62.

Hinfray N, Palluel O, Turies C, Cousin C, Porcher JM, Brion F. Brain and gonadal aromatase as potential targets of endocrine disrupting chemicals in a model species, the zebrafish (Danio rerio). Environ Toxicol 2006b; 21: 332-7.

Jobling S, Sheahan D, Osborne JA, Matthiessen P, Sumpter JP. Inhibition of testicular growth in Rainbow trout (Oncorhynchus mykiss) exposed to estrogenic alkylphenolic chemicals. Environ Toxicol Chem 1996; 15: 194-202.

Jobling S, Nolan M, Tyler CR, Brighty G, Sumpter JP. Widespread sexual disruption in wild fish. Environ Sci Technol 1998; 32: 2498-2506.

Jobling S, Beresford N, Nolan M, Rodgers-Gray T, Brighty GC, Sumpter JP, Tyler CR. Altered sexual maturation and gamete production in wild roach (Rutilus rutilus) living in rivers that receive treated sewage effluents. Biol Reprod 2002; 66: 272-81. 
Jobling S, Tyler CR. Endocrine disruption in wild freshwater fish. Pure Appl Chem 2003; 75:

642

643

644

645

646

647

648

649

650

651

652

653

654

655

656

657

658

659

660

661

662 2219-2234.

Karels A, Soimasuo M, Oikari A. Effects of pulp and paper mill effluents on reproduction, bile conjugates and liver MFO (mixed function oxygenase) activity in fish at Southern Lake Saimaa, Finland. Water Sci Technol 1999; 40: 109-114.

Labadie P, Budzinski H. Determination of steroidal hormone profiles along the Jalle d'Eysines River (near Bordeaux, France). Environ Sci Technol 2005; 39: 5113-20.

Lange A, Katsu Y, Ichikawa R, Paull GC, Chidgey LL, Coe TS, Iguchi T, Tyler CR. Altered sexual development in roach (Rutilus rutilus) exposed to environmental concentrations of the pharmaceutical 17 alpha-ethinylestradiol and associated expression dynamics of aromatases and estrogen receptors. Toxicol Sci 2008; 106: 113-123.

Lavado R, Thibaut R, Raldua D, Martin R, Porte C. First evidence of endocrine disruption in feral carp from the Ebro River. Toxicol Appl Pharmacol 2004; 196: 247-257.

Laville N, Balaguer P, Brion F, Hinfray N, Casellas C, Porcher JM, Ait-Aissa S. Modulation of aromatase activity and mRNA by various selected pesticides in the human choriocarcinoma JEG-3 cell line. Toxicology 2006; 228: 98-108. 
666

Le Bail JC, Champavier Y, Chulia AJ, Habrioux G. Effects of phytoestrogens on aromatase, 3beta and 17beta-hydroxysteroid dehydrogenase activities and human breast cancer cells. Life Sci 2000; 66: 1281-91.

Lister AL,Van Der Kraak GJ. Endocrine disruption: Why is it so complicated? Water Qual Res J Can 2001; 36: 175-190.

Louiz I, Kinani S, Gouze ME, Ben-Attia M, Menif D, Bouchonnet S, Porcher JM, BenHassine OK, Aït-Aïssa S. Monitoring of dioxin-like, estrogenic and anti-androgenic activities in sediments of the Bizerta lagoon (Tunisia) by means of in vitro cell-based bioassays: Contribution of low concentrations of polynuclear aromatic hydrocarbons (PAHs). Sci Total Environ 2008; 402: 318-329.

Marshall Adams S, Crumby WD, Greeley MS, Shugart LR, Saylor CF. Responses of fish populations and communities to pulp mill effluents: A holistic assessment. Ecotox Environ Safe $1992 ; 24: 347-360$.

Mazet A, Keck G, Berny P. Concentrations of PCBs, organochlorine pesticides and heavy metals (lead, cadmium, and copper) in fish from the Drôme river: Potential effects on otters (Lutra lutra). Chemosphere 2005; 61: 810-816.

Menuet A, Pellegrini E, Brion F, Gueguen MM, Anglade I, Pakdel F, Kah O. Expression and estrogen-dependent regulation of the zebrafish brain aromatase gene. J Comp Neurol 2005; 485: 304-20. 
Miles-Richardson SR, Kramer VJ, Fitzgerald SD, Render JA, Yamini B, Barbee SJ, Giesy JP. Effects of waterborne exposure of 17 [beta]-estradiol on secondary sex characteristics and gonads of fathead minnows (Pimephales promelas). Aquat Toxicol 1999; 47: 129-145.

Minier C, Caltot G, Leboulanger F, Hill EM. An investigation of the incidence of intersex fish in Seine-Maritime and Sussex regions. Analusis 2000; 28: 801-806.

Monod G, De Mones A, Fostier A. Inhibition of ovarian microsomal aromatase and follicular estradiol suppression by imidazole fungicides in rainbow trout. Mar Environ Res 1993; 35: 153-157.

Munkittrick KR, Mcmaster ME, Mccarthy LH, Servos MR, Van Der Kraak GJ. An overview of recent studies on the potential of pulp-mill effluents to alter reproductive parameters in fish. J Toxicol Env Health-Pt B-Crit Rev 1998; 1: 347-371.

Noaksson E, Tjarnlund U, Bosveld ATC, Balk L. Evidence for Endocrine Disruption in Perch (Perca fluviatilis) and Roach (Rutilus rutilus) in a Remote Swedish Lake in the Vicinity of a Public Refuse Dump. Toxicol Appl Pharmacol 2001; 174: 160-176.

Orlando EF, Davis WP, Guillette LJ Jr. Aromatase activity in the ovary and brain of the eastern mosquitofish (Gambusia holbrooki) exposed to paper mill effluent. Environ Health Perspect 2002; 110 Suppl 3: 429-33. 
Pasmanik M, Callard GV. Changes in brain aromatase and 5 alpha-reductase activities correlate significantly with seasonal reproductive cycles in goldfish (Carassius auratus). Endocrinology 1988; 122: 1349-1356.

Pelissero C, Lenczowski MJP, Chinzi D, Davail-Cuisset B, Sumpter JP, Fostier A. Effects of flavonoids on aromatase activity, an in vitro study. J Steroid Biochem Mol Biol 1996; 57: 215-223.

Pillon A, Boussioux AM, Escande A, Ait-Aissa S, Gomez E, Fenet H, Ruff M, Moras D, Vignon F, Duchesne MJ, Casellas C, Nicolas JC, Balaguer P. Binding of estrogenic compounds to recombinant estrogen receptor-alpha: application to environmental analysis. Environ Health Perspect 2005; 113: 278-84.

Randak T, Zlabek V, Pulkrabova J, Kolarova J, Kroupova H, Siroka Z, Velisek J, Svobodova Z, Hajslova J. Effects of pollution on chub in the River Elbe, Czech Republic. Ecotoxicol Environ Saf 2009; 72: 737-46.

Rosenfeld H, Meiri I, Elizur A. Gonadotropic regulation of oocyte development. In : Babin PJ, Cerda J, Lubzens E, Editors. The fish oocyte : from basic studies to biotechnological applications. Springer, Dordrecht, 2007, pp175-202.

Sanchez W, Katsiadaki I, Piccini B, Ditche JM, Porcher JM. Biomarker responses in wild three-spined stickleback (Gasterosteus aculeatus L.) as a useful tool for freshwater biomonitoring: A multiparametric approach. Environ Int 2008; 34: 490-498. 
Sanderson JT, Boerma J, Lansbergen GWA,Van Den Berg M. Induction and Inhibition of Aromatase (CYP19) Activity by Various Classes of Pesticides in H295R Human Adrenocortical Carcinoma Cells. Toxicol Applied Pharmacol 2002; 182: 44-54.

Schlinger BA, Creco C, Bass AH. Aromatase activity in the hindbrain vocal control region of a teleost fish: divergence among males with alternative reproductive tactics. P Roy Soc Lond B Bio 1999; 266: 131-136.

Sumpter JP, Jobling S. Vitellogenesis as a biomarker for estrogenic contamination of the aquatic environment. Environ Health Perspect 1995; 103 Suppl 7: 173-8.

Sumpter JP. Xenoendocrine disrupters -- environmental impacts. Toxicol Lett 1998; 102-103: $337-342$.

Tyler CR, Spary C, Gibson R, Santos EM, Shears J, Hill EM. Accounting for differences in estrogenic responses in rainbow trout (Oncorhynchus mykiss : Salmonidae) and roach (Rutilus rutilus : Cyprinidae) exposed to effluents from wastewater treatment works. Environ Sci Technol 2005; 39: 2599-2607.

Van Aerle R, Nolan TM, Jobling S, Christiansen LB, Sumpter JP, Tyler CR. Sexual disruption in a second species of wild cyprinid fish (the gudgeon, Gobio gobio) in United Kingdom freshwaters. Environ Toxicol Chem 2001; 20: 2841-7.

Vos JG, Dybing E, Greim HA, Ladefoged O, Lambre C, Tarazona JV, Brandt I, Vethaak AD. Health effects of endocrine-disrupting chemicals on wildlife, with special reference to the European situation. Crit Rev Toxicol 2000; 30: 71-133. 
762 Whyte JJ, Jung RE, Schmitt CJ, Tillitt DE. Ethoxyresorufin-O-deethylase (EROD) activity in 763 fish as a biomarker of chemical exposure. Crit Rev Toxicol 2000; 30: 347-570.

764

765 Zlabek V, Randak T, Kolarova J, Svobodova Z, Kroupova H. Sex differentiation and 766 vitellogenin and 11-ketotestosterone levels in chub, Leuciscus cephalus L., exposed to 17

767 beta-estradiol and testosterone during early development. Bull Environ Contam Toxicol 2009; 768 82: $280-4$

769 